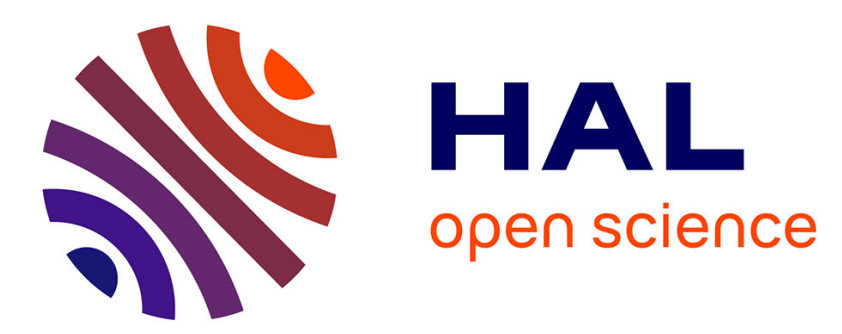

\title{
Effect of structural relaxation on the plasticity of the Fe78b13 Si9 amorphous alloy
}

\author{
L. Bresson, Mireille L. Harmelin-Vivien
}

\section{To cite this version:}

L. Bresson, Mireille L. Harmelin-Vivien. Effect of structural relaxation on the plasticity of the Fe78b13 Si9 amorphous alloy. Revue de Physique Appliquée, 1988, 23 (4), pp.717-717. 10.1051/rphysap:01988002304071700 . jpa-00245872

\section{HAL Id: jpa-00245872 https://hal.science/jpa-00245872}

Submitted on 1 Jan 1988

HAL is a multi-disciplinary open access archive for the deposit and dissemination of scientific research documents, whether they are published or not. The documents may come from teaching and research institutions in France or abroad, or from public or private research centers.
L'archive ouverte pluridisciplinaire HAL, est destinée au dépôt et à la diffusion de documents scientifiques de niveau recherche, publiés ou non, émanant des établissements d'enseignement et de recherche français ou étrangers, des laboratoires publics ou privés. 


\title{
EFFECT OF STRUCTURAL RELAXATION ON THE PLASTICITY OF THE Fe ${ }_{78} \mathrm{~B}_{13} \mathrm{Sig}$ AMORPHOUS ALLOY
}

\author{
L. Bresson, M. Harmelin
}

CNRS-CECM, 15, rue G. Urbain, F-94407 Vitry-sur-Seine Cedex, France

Mechanical properties of metallic amorphous alloys are very sensitive to the metastable structural state. Whereas plastic instabilities associated with shear bands do not allow the study of plastic behaviour by means of uniaxial tensile tests, bending tests between parallel platens are a suitable way to investigate the plasticity of this kind of materials.

In order to regulate the strain rate of the ribbon surface at the apex, platen motion was step-motor driven and was monitored by a computer which controlled in real time the platen speed and position (Fig.1).

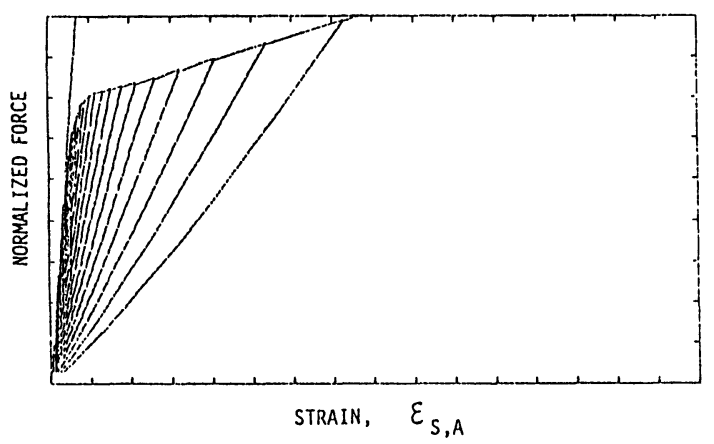

Fig.1-Renormalized bending test curve (with elastic unloadings).

The plasticity of the $\mathrm{Fe}_{78} \mathrm{~B}_{13} \mathrm{Si}_{9}$ amorphous alloy was anaiysed by means of cumulative strain increments sollicitation mode associated with stress relaxation measurements at each strain increment.

The structural evolution induced by annealing was studied in comparison with the as-quenched state and was investigated by both bending tests and differential scanning calorimetry (DSC).

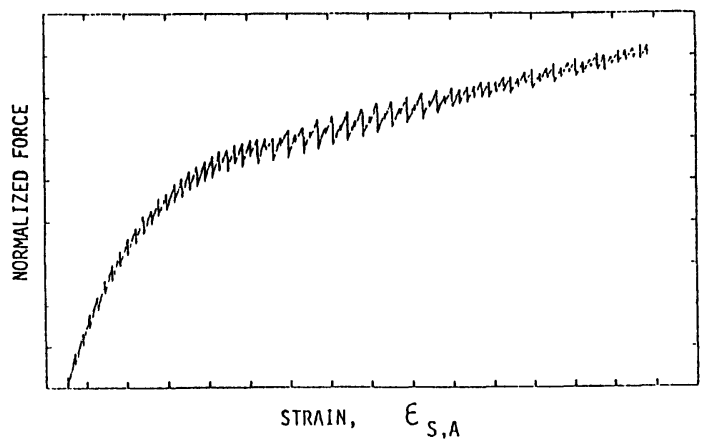

Fig.2-Incremental bending test curve associated with stress relaxation measurement.
The results obtained show that, whatever the metastable structural state, there exists a strong interaction between the plastic component of each strain step and the stress rcla$x$ ation measured. This last point leads to a periodicity of the stress relaxation amplitude (Fig.2) of the previous step, the greater the elastic component - and thus the smaller the plastic component - of the next strain step.

Moreover (Fig.3), the stress relaxation amplitude decreases as the isothermal annealming time is increased. This is well correlated to structural evolution as detected by DSC (Fig.4).

This kind of test allows to study the amorphous statc evolution toward further embrittlement appearance.

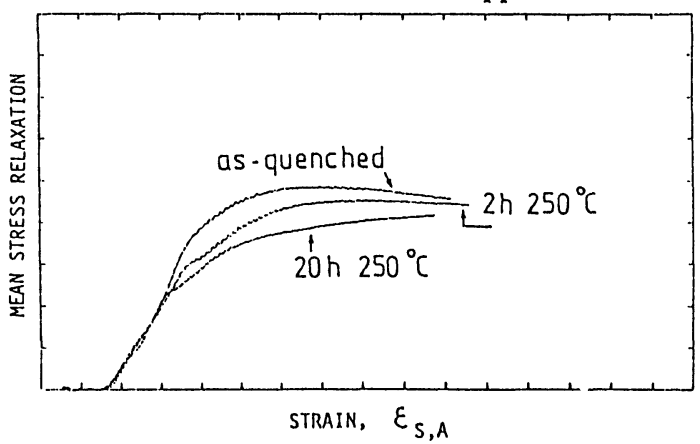

Fig.3- Stress relaxation evolution with struclural relaxation.

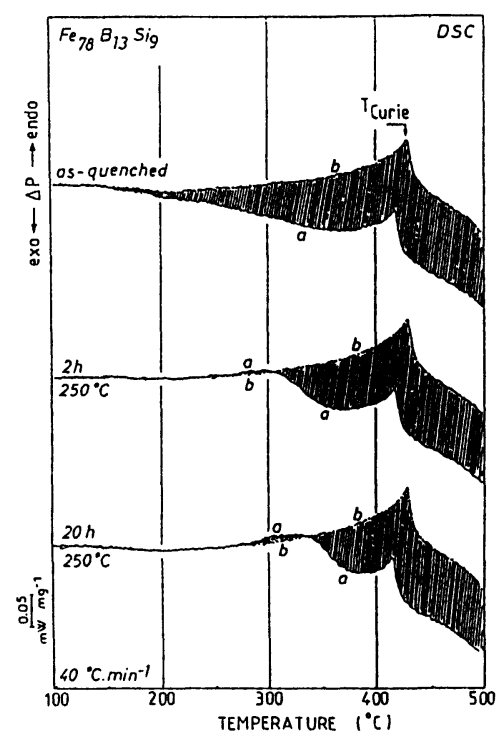

Fig.4-DSC evidence of the annealing induced structural relaxation. 